\title{
Effect of Spraying Seaweed Extracts and Silicon on yield and Fruit Quality of Zaghloul Date Palms Grown under Sandy Soil Conditions
}

\section{Mohamed Ahmed Badran}

Horticulture Research Institute - Agriculture Research Center - A. R. E

Received on: 16/10/2016

Accepted for publication on: 20/10/2016

\section{Abstract}

This study was carried out through 2014 and 2015 in a private date palm orchard located in New Assuit City district, Assuit Governorate to study the effect of spraying with different concentrations of two seaweed extraction, (Eprosil-k at 4\%) and (Oligo-x at 2 or 4\%) either alone or with silicon nutrient at $(0.5 \%)$, on yield and fruit quality of Zaghloul date palms. palms sprayed three times during grown seasons (first of April, May and June) with Seaweed extracts at 2 or $4 \%$ either alone or with silicon were very effective on improving yield and fruit quality (fruit weight, dimensions, total soluble solids and sugar contents) in comparison with control treatment. The promotion on these characters was observed when the concentrations of Oligo-x (Seaweed extract compound) were increased from 2 to $4 \%$. The best results with regard to yield and fruit quality of Zaghloul date palms were obtained due to spray the palms three times with a mixture of seaweed extract (Oligo-x at 4\%) and silicon nutrient at $0.5 \%$.

Keywords: Seaweed, Date palm, Yield, Biofretilization, Foliar spraying.

\section{Introduction}

Date palm (Phoenix dactylifera L.) is an important fruit crop of the arid regions in the world. Especially in the Middle East and North Africa, where it has been cultivated since ancient times and is closely associated with the life and culture of the people in these regions. Egypt is considered as the leader of Arab countries in producing dates (FAO 2009).

Date palm cultivars divided into three main types according to its fruit moisture content, i.e. Soft, Semi-dry and dry cultivars (Selim et al., 1968). Date palm trees could grow under unfavorable conditions where many of other fruit species could not grow. Date palm is the most common fruit tree grown in semiarid and arid- regions. It plays an important role in the protection of interplant cropping systems and the stabilization of the ecological system (Hasnaoui et al.
2011). For this reason date palm is considered one of the suitable trees, which could be cultivated in the new reclaimed desert regions.

Low yield of palms grown under sandy soil is considered a major problem that faces growers. Likewise, modern agriculture is searching for new biotechnologies that would allow for reduction in the use of chemical inputs without negatively affecting crop yield or the farmer's income. Similarly, finding out recent techniques for promoting yield without causing any environmental pollution is an important task for pomologists. Investigations on compounds capable of reducing the sensitivity of fruit crops to all stresses and at the same time to unfavorable conditions are of great importance. Novel bioactive compounds from the marine environment have become a common practice in agriculture, which repre- 
sents a rich natural resource of many functional ingredients. Previous studies showed that using seaweed extract at various concentrations and frequencies had an announced promotion on growth and fruiting of all evergreen fruit crops (El- Sawy, 2005; Gamal, 2006 Mouftah, 2007; ElSayed- Esraa, 2010; Abdelaal et al., 2012; Mahmoud, 2012 Ahmed et al., 2013a and 2013b; Mohamed and ElSehrawy 2013 and Gamal, 2013)، The application of seaweed extract which contains most nutrients, organic compounds, enzyme vitamins antioxidants, amino acids and natural hormones is fast becoming an accepted practice. It increase yield quantitatively and qualitatively in various fruit crops (Soliman et al., 2000 and Khan et al., 2009). The results of Abdelaal et al., 2012, Mahmoud 2012, Gamal2013, Abd El Aty 2015 supported the beneficial effects of using seaweed extract on fruiting on different fruit crops.

Moreover, silicon plays an important role in increasing and enhancing with standing of fruit crops to biotic and abiotic stresses, photosynthesis, nutrient and water uptake, plant pigments and all cell division (Epstein 1999 and Ma 2004). Previous studies exhibited that using all sources of silicon was very effective in improving yield and fruit characteristics in various fruit crops (AlWasfy 2014, El-Khawaga and Mansour 2014, and Abd El-Wahab 2015).

Consequently, this investigation aimed to study the effect of two Seaweed extract compounds (Eprosil-k at $4 \%$ ) and (Oligo-x at 2 or $4 \%$ ) either alone or with silicon nutrient at $(0.5 \%)$, on fruiting of Zaghloul palms grown under new reclaimed sandy soil and to optimize the best concentration.

\section{Material and Methods}

This study was conducted during 2014 and 2015 seasons in a private date palm orchard situated in New Assuit City district, Assuit Governorate on eighteen years old Zaghloul date palms (soft date palm cultivar). The selected palms are uniform in vigor healthy, good physical conditions, free from insects, diseases and damages. The number of bunches per palm was adjusted to eight bunches and leaf / bunch ratio was maintained at 8:1 (Hassaballa et al., 1983). The selected palms were irrigated with well water (EC $600 \mathrm{ppm}$ ) through drip irrigation system. Hand pollination was achieved by inserting five fresh male strands into the center of each female spathe using the same source of pollens to avoid residues of metaxenia.

Seaweed extracts (Oligo-x) was purchased from AGAS (Arabian group for agricultural service) company. The Oligo-x compositions were oligosaccharide (3\%), algnic acid $(5 \%)$, phytin $(0.003 \%)$, menthol $(0.001 \%)$, natural growth regulators (cytokinine, 0.001; indol acetic acid, $0.0002 \%$ and pepsin, $0.02 \%$ ) and minerals (potassium oxide, 12\% ; phosphorus oxide, $0.5 \%$; N, $1 \%$; $\mathrm{Zn}$, $0.3 \%$; $\mathrm{Fe}, 0.2 \%$ and $\mathrm{Mn}, 0.1 \%)$. Eprosil-k is manufactured by Opal Company with following composition: potassium (k) $10 \%$, silicon (sio2) 20\% and Ascophylium nodosum L.(Seaweed extract) $5 \%(\mathrm{w} / \mathrm{w})$. Also, Silicon nutrient $(25 \% \mathrm{Si}$ and $10 \% \mathrm{~K} 2 \mathrm{O}$ ) was purchased from ElGaneem Company Egypt. 
Experimental units were arranged in a randomized complete block design with three replicates, one palm per each. This Experiment included the following six treatments:

1- Control in which palms were sprayed with water only.

2- Spraying seaweed extract (Oligo-x at 2\%).

3- Spraying seaweed extract (Oligo-x at 4\%).

4- Spraying seaweed extract (Oligo-x at 2\%) with Silicon nutrient at $0.5 \%$.

5- Spraying Oligo-x seaweed extract (Oligo-x at 4\%) with Silicon nutrient at $0.5 \%$.

6- Spraying seaweed extract (Eprosil-k at 4\%).

Seaweed extract were sprayed three times at the first of April, May and June in both seasons, spraying was done till runoff using Triton $B$ as a wetting agent.

The following indices were studied and recorded:

Average bunch weight and total yield: All fruit bunches on each palm were harvested when the fruits reached to full color stage, average bunch weight and total yield were recorded.

Physical and chemical properties of fruits: a random sample of 100 fruits collected at harvest time of each replicate (from each palm). Fruit characteristics included weight of fruit, pulp and seed, fruit volum and fruit dimensions (axial and equatorial diameter), and Pulp thickness. Total soluble solids (T.S.S) content were determined by hand refractometer. Total and reducing sugars content were determined according to the method of Lane and Eynon as described in the A. O. A. C. (1980). Also; acidity content was determined as $\mathrm{g}$ malic acid per $100 \mathrm{~g}$ pulp (Hussein et al 1993). Data were subjected to statistical analysis according to Snedecor and Cochran (1990). The treatment means were compared using Least Significant Difference (LSD) at 5\% level.

\section{Results and Discussion}

\section{Bunch weight and yield per palm:}

Data illustrated in Table (1) showed that a significant promotion on the bunch weight and consequently yield per palm in response to treate the palms with different sources and concentrations of seaweed extracts either alone or with silicon nutrient at $0.5 \%$ in compared with control. Spraying Oligo extract at $4 \%$ with silicon at $0.5 \%$ (treatment 5) gave the highest values of bunch weight (22.17 and $22.95 \mathrm{~kg}$ and total yield per palm (176 and $176.58 \mathrm{~kg}$ ) during seasons 2014 and 2015 , respectively compared with the other investigation treatments. The percent of increase in bunch weight compared with control were about (36.43 and $41.84 \%$ ) while it was about (57.90 and $53.90 \%$ ) in total yield during the two experimental seasons, respectively There was a gradual promotion on bunch weight and yield per palm with increasing concentration of Oligo extract from 2 to $4 \%$ either alone or with silicon treatments. Also, adding Silicon at $0.5 \%$ to Oligo-x at $2 \%$ or $4 \%$ was performance better than Eprosil-k (which contains $20 \%$ silicon) in respect to bunch weight and total yield per palm during the two seasons. 
Table 1. Effect of Seaweed extracts and silicon spraying on bunch weight and total yield of "Zaghloul" date palm during 2014 and 2015 seasons

\begin{tabular}{|l|c|c|c|c|}
\hline \multirow{2}{*}{ Treatments } & \multicolumn{2}{c|}{ Bunch weight (kg) } & \multicolumn{2}{c|}{ Total yield/palm (kg) } \\
\cline { 2 - 5 } & $\mathbf{2 0 1 4}$ & $\mathbf{2 0 1 5}$ & $\mathbf{2 0 1 4}$ & $\mathbf{2 0 1 5}$ \\
\hline Control & 16.25 & 16.18 & 111.40 & 114.73 \\
\hline Oligo-x at 2\% & 17.50 & 17.43 & 132.00 & 133.67 \\
\hline Oligo-x at 4\% & 20.65 & 21.65 & 149.73 & 150.58 \\
\hline Oligo-x at 2\%+ Silicon at 0. 5\% & 19.50 & 20.10 & 155.00 & 161.51 \\
\hline Oligo-x at 4 \%+ Silicon at 0.5\% & 22.17 & 22.95 & 176.00 & 176.58 \\
\hline Eprosil-k at 4\% & 18.25 & 18.61 & 144.00 & 145.00 \\
\hline L S D at 5\% & 0.49 & 0.66 & 3.31 & 2.57 \\
\hline
\end{tabular}

\section{Fruit physical properties:}

The results showed that a significant difference among treatments in most physical properties of fruit Table (2). There was a significantly increase in the fruit and pulp weight, fruit volum and fruit dimensions (height and diameter) compared with control when the palms treated with Seaweed extract at 2 or $4 \%$ either alone or with Silicon nutrient at 0.5 $\%$. The highest values of such fruit properties were obtained from palms sprayed with Seaweed extract (Oligo$\mathrm{x}$ at $4 \%$ ) with Silicon at $0.5 \%$ (treatment 5) compared with the other treatments during the two experimental seasons, the percent of increase in fruit weight were about 42 and $41 \%$ during the two experimental seasons respectively while it was about 47 and $46 \%$ on pulp weight compared with control, also percent of increase in fruit size was about $41 \%$ in the two experimental seasons compared with control the percent of increase in fruit heigh was about 9.6 and $9.7 \%$ compared with control while it was about 27 and 26\% in fruit diameter during the two experimental seasons, respectively. In the other hand, seed weight and pulp thickness did not significantly affected by various experimental treatments during the two seasons. In other words, the increase in fruit weight by treatments could be mainly attributed to the increase in pulp weight without regard to the changes of seed weight.

Table 2. Effect of Seaweed extracts and silicon spraying on some fruit physical characteristics of Zaghloul date palm during 2014 and 2015 seasons.

\begin{tabular}{|c|c|c|c|c|c|c|c|c|c|c|c|c|c|c|}
\hline \multirow[t]{2}{*}{ Spraying treatments } & \multicolumn{2}{|c|}{$\begin{array}{c}\text { Fruit } \\
\text { weight } \\
\text { (g) }\end{array}$} & \multicolumn{2}{|c|}{$\begin{array}{c}\text { Fruit } \\
\text { volum } \\
(\mathrm{cm})\end{array}$} & \multicolumn{2}{|c|}{$\begin{array}{c}\text { Pulp } \\
\text { weight } \\
\text { (g) }\end{array}$} & \multicolumn{2}{|c|}{$\begin{array}{c}\text { Fruit } \\
\text { height } \\
(\mathrm{cm})\end{array}$} & \multicolumn{2}{|c|}{$\begin{array}{c}\text { Fruit } \\
\text { diameter } \\
\text { (cm) }\end{array}$} & \multicolumn{2}{|c|}{$\begin{array}{c}\text { Seed } \\
\text { weight } \\
(\mathrm{g}) \\
\end{array}$} & \multicolumn{2}{|c|}{$\begin{array}{l}\text { Pulp } \\
\text { thickness } \\
\text { (cm) }\end{array}$} \\
\hline & 2014 & 2015 & 2014 & 2015 & 2014 & 2015 & 2014 & 2015 & 2014 & \begin{tabular}{|l|l}
2015 \\
\end{tabular} & 2014 & 2015 & 2014 & 2015 \\
\hline Con & 16.13 & 16.03 & 17.37 & 17.34 & 14.52 & 14.48 & 5.08 & 5.13 & 2.15 & 2.20 & 1.60 & 1.55 & 0.59 & 0.61 \\
\hline Olig & 17.51 & 17.38 & 18.57 & 18.58 & 15.92 & 15.86 & 5.21 & 5.28 & 2.55 & 2.60 & 1.58 & 1.52 & 0.63 & 0.63 \\
\hline Oligo- & 18.58 & 18.18 & 19.87 & 19.87 & 17.03 & 16.6 & 5.37 & 5.41 & 2.65 & 2.69 & 1.55 & 1.57 & 0.61 & 0.61 \\
\hline Oligo & 21.75 & 21.89 & 24.44 & 24.44 & 20.19 & 20.32 & 5.40 & 5.45 & 2.62 & 2.67 & 1.56 & 1.57 & 0.65 & 0.65 \\
\hline Oligo-x at $4 \%+\mathrm{Si}$ & 22.95 & 22.68 & 24.48 & 24.48 & 21.35 & 21.12 & 5.57 & 5.63 & 2.72 & 2.78 & 1.60 & 1.56 & 0.66 & 0.66 \\
\hline Eprosil-k at $4 \%$ & 18.30 & 18.38 & 19.61 & 19.61 & 16.76 & 16.79 & 5.28 & 5.24 & 2.58 & 2.65 & 1.54 & 1.59 & 0.63 & 0.63 \\
\hline LSD at $5 \%$ & \begin{tabular}{|l|}
0.71 \\
\end{tabular} & \begin{tabular}{|l|}
0.80 \\
\end{tabular} & 1.00 & 0.99 & 0.85 & 0.77 & 0.06 & 0.04 & 0.04 & 0.05 & $\mathrm{~N} \mathrm{~S}$ & N S & $\mathrm{N} \mathrm{S}$ & $\mathrm{N} \mathrm{S}$ \\
\hline
\end{tabular}




\section{Fruit chemical properties:}

Data tabulated in Table (3) showed the effect of spraying by two of Seaweed extracts (Eprosil-k) and (Oligo-X either alone or with Silicon nutrient) three times on fruit content of total soluable solids (T S S), sugar contents (total, reducing and non reducing) and acidity of Zaghloul date cultivar. It has been evidenced that spraying palms three times with Seaweed extracts either alone or with silicon resulted in significant increase in T S S and sugar content (total and reducing) compared with control, which gave the lowest values in such chemical properties during the two experimental seasons. Spraying Oligo-x Seaweed extract three times at $4 \%$ with silicon nutrient at $0.5 \%$ (treatment 5) gave the highest values of $\mathrm{T} \mathrm{S} \mathrm{S}$, total and reducing sugars compared with the other treatments.

The promotion on fruit quality was associated with increasing concentration of Oligo-x extract from 2 to $4 \%$ when it used either alone or with silicon, also a significantly increase in TSS and reducing as well as total sugars obtained under Oligo- $x$ at $4 \%$ with Silicon at $0.5 \%$ treatment compared with Eprosil-k at 4\% treatment was noticed.

Furthermore, according to nonreducing sugars data presented in Table (3) showed that the differences between treatments were significantly during the two seasons. Spraying Oligo Seaweed extract at $2 \%$ three times gave the highest non reducing sugars values (6.62 and 6.39\%) compared with the other experimental treatments during the two experimental seasons, respectively. While, the lowest values was obtained by sprayed palms with Eprosil-k (Seaweed extract) at $4 \%$ three times (4.02 and $4.32 \%$ ).

In regard to total acidity of fruits, the results in Table (3) showed that there are no significant differences in total acidity between different treatments including the control. This was true in both seasons.

The previous positive action of Seaweed extract on growth characters and fruiting of fruit crops might be attributed to its higher content of organic matter, proteins, alginic acid, $\mathrm{N}, \mathrm{P}, \mathrm{K}, \mathrm{Mg}, \mathrm{Ca}, \mathrm{S}, \mathrm{Fe}, \mathrm{Mn}, \mathrm{Zn}, \mathrm{Cu}$, $\mathrm{B}$, cytokinins and IAA. In addition, it's content of enzymes, vitamins, antioxidants and amino acids. These are responsible for enhancing cell division, photosynthesis, and building of plant pigments and increasing the tolerance of plant to all stresses (James, 1994; Soliman et al., 2000 and Khan et al. (2009)). These results regarding the enhancing effect of seaweed extract on the yield and fruit quality could be supported by previous results demonstrated by Abdelaal et al. (2012), Mahmud (2012), Gamal (2013), Abd El-Aaty (2015) and Farouk et al (2015) who found that treating Al-Saidey palms three times with seaweed extract and/or potassium silicate each at $0.05-0.4 \%$ was very effective in improving yield and fruit quality over the check treatment. The promotion was materially associated with increasing concentrations. Meaningless promotion on these characters was observed with increasing concentrations of both materials from 0.2 to $0.4 \%$. The best results with regard to yield and fruit quality of Al-Saidey date palms grown under New Valley conditions were obtained 
due to spraying the palms three times with a mixture of seaweed extract and potassium silicate each at $0.2 \%$. Also Malaka et al (2016) indicated that spraying inflorescences date palm with algae extract and/or potassium nitrate had a significant effect on yield, fruit physical and chemical characteristics of Medjool date palm when compared to the check treatment. The effective was in proportional to the increase in concentrations of both materials. The superior treatment concerning yield and fruit quality was spraying Medjool date palms two times with high doses of combined treatment (1\% algae extract $+2 \%$ potassium nitrate) in the two experimental seasons.
The current findings regarding the promoting effect of silicon on growth and fruiting of fruit crops are in harmony with those obtained by Gad El-Kareem (2012), Al-Wasfy (2014), El-Khawaga (2014), ElKhawaga and Mansour 2014, Gad ElKareem et al. (2014), Eshmawy 2015, Abd El-Wahab (2015) and Badran et al (2015) who found that Spraying "Zaghloul" and "Samany" date palm inflorescences grown in new reclaimed soil under Assuit conditions with different sources of potassium silicate at different concentrations had a positive effect on fruit set, yield and fruit quality.

Table 3. Effect of seaweed extracts and Silicon spraying on some fruit chemical propertis of "Zaghloul" dates during 2014 and 2015 seasons

\begin{tabular}{|c|c|c|c|c|c|c|c|c|c|c|}
\hline \multirow[t]{2}{*}{ Treatments } & \multicolumn{2}{|c|}{ T S S \% } & \multicolumn{2}{|c|}{ Total sugar\% } & \multicolumn{2}{|c|}{$\begin{array}{l}\text { Reducing sug- } \\
\text { ars } \%\end{array}$} & \multicolumn{2}{|c|}{$\begin{array}{l}\text { Non-reducing } \\
\text { sugars } \%\end{array}$} & \multicolumn{2}{|c|}{ Acidity } \\
\hline & 2014 & 2015 & 2014 & 2015 & 2014 & 2015 & 2014 & 2015 & 2014 & 2015 \\
\hline Control & 21.80 & 2.13 & 20.13 & 20.32 & 15.22 & 15.88 & 4.92 & 4.44 & 0.22 & 0.21 \\
\hline Oligo at $2 \%$ & 24.00 & 24.44 & 23.55 & 23.72 & 16.93 & 17.33 & 6.62 & 6.39 & 0.20 & 0.21 \\
\hline Oligo at $4 \%$ & 28.07 & 28.36 & 24.47 & 24.42 & 19.12 & 19.20 & 5.35 & 5.22 & 0.19 & 0.20 \\
\hline Oligo at $2 \%+\mathrm{Si}$ at $0.5 \%$ & 24.33 & 24.60 & 22.43 & 22.53 & 19.23 & 19.57 & 3.20 & 2.97 & 0.19 & 0.19 \\
\hline Oligo at $4 \%+\mathrm{Si}$ at $0.5 \%$ & 28.20 & 28.57 & 26.63 & 26.11 & 20.26 & 20.40 & 6.37 & 5.71 & 0.18 & 0.19 \\
\hline Eprosil $\mathrm{k}$ at $4 \%$ & 24.13 & 24.80 & 21.86 & 22.24 & 17.77 & 17.91 & 4.09 & 4.32 & 0.21 & 0.21 \\
\hline L S D at $5 \%$ & 1.43 & 1.17 & 0.74 & 0.97 & 0.70 & 0.60 & 0.80 & 0.83 & $\mathrm{~N} \mathrm{~S}$ & N S \\
\hline
\end{tabular}

\section{Conclusion}

From the results presented in this study, we can concluded that spraying Zaghloul date palms grown under new reclaimed sandy soil conditions three times (at first of April, May and June) with Oligo-x seaweed extract at $4 \%$ with Silicon at $0.5 \%$ was the promising treatment, since it improved yield. Also, it increased height, diameter of fruit, fruit weight, pulp weight and total soluble solids as well as sugars content (reducing and total). This proved that used of seaweed extracts in agricultural practices had economic impact.

\section{References}

Abdelaal, A.M.K.; Ahmed, F.F. and Mahmoud, Kh. M. (2012). Partial replacement of chemical N fertilizers in Balady mandarin orchard through application of extracts of yeast, seaweed and farmyard manure. Minia J. of Agric. Res. \& Develop. Vol. (32) No. 1 pp. 129148.

Abd El-Aaty, M.S.H. (2015). Relation of fruiting in Sakkoti and Bartemoda date palms with spraying seaweed extract. M. Sc. Thesis Fac. of Agric. Minia Univ. Egypt.

Abd El-Wahab, H.A.M. (2015). Response of Succary mango trees to foliar application of silicon and bo- 
ron. M.Sc. Thesis Fac. of Agric. Minia Univ. Egypt.

Ahmed, F.F., Akl, M.M.A. and Oraby A.A.F. (2013a). Partial replacement of inorganic Nitrogen fertilizer by spraying some vitamin, yeast and seaweed extract to Ewaise mango orchard under Upper Egypt conditions. Stem Cell (3): 110- 120.

Ahmed, F.F.; Mansour, A.E.M.; Abd ElRahman, M.A. Merwad, M.A. and Mostafa, K.A. (2013b). Response of Valencia orange trees to foliar application of roselle, turmeric and seaweed extracts. J. of Applied Sci. res. 9 (1): 960-964.

Ahmed, F.F.; Mohamed, H.A.A and Jad El- Kareem, M.R. (2014). The promotive effect of seaweed extract in fruiting of Zaghloul date palms grown under Minia region. 5 International Date Palm Conf., 1618 Mar. Emirates Palace Abu Dhabi United Arab Emirates

Al-Wasfy, M.M. (2014). The synergistic effects of using silicon with some vitamin on growth and fruiting of Flame seedless grapevines. Stem Cell 5(1): 8-13.

Association of Official Agricultural Chemists (A.O.A.C.) (1980). Official Methods of Analysis (A.O.A.C), 12th Ed., Benjamin Franklin Station, Washington D.C., U.S.A. pp.490-510.

Badran, A. M. F.; HodaS. H. Aly ;O.A. Khaliland A.Y.M. Ahmed (2015). Improving Fruit Quality and Yield of Zaghloul and Samany Date Cultivars by Spraying with Silicon Nutrient Assiut J. Agric. Sci., (46) No. (6) 2015(57-66).

El-Khawaga, A.S. (2014). Impact of vitamins B and C, glutamic acid and silicon on fruiting of Superior grapevines. World Rural Observations 6(4): 57-62.
.El-Khawaga, A.S. and Mansour, A.G.M. (2014). Promoting productivity of Washington Navel orange trees by using some crop seed sprout extracts, silicon and glutathione. Middle East Journal of Applied Sciences, 4(3): 779-785.

El- Sawy, Y.A. (2005). Studies on the effect of some organic fertilizers, ammonium nitrate and the biofertilizer (Algae extract) on growth and productivity of Williams banana (Musa cavendishiiL.). M. Sc. Thesis Fac. of Agric Minia Univ.

El-Sayed, Esraa. M. H. (2010). Behaviour of Ewaise mango trees to foliar application of some nutrients and seaweed extract. Ph. D. Thesis Fac. of Agric. Minia Univ. Egypt.

Epstein, E. (1999). Silicon. Annl. Rev. Plant. Physiol. Plant Mol-Bio. 50:641-664.

Eshmawy, E.M.S. (2015). Relation of fruiting in Saeidy date palm with spraying salicylic acid and Seaweed extract. Ph. D. Thesis Fac. of Agric. Minia Univ. Egypt.

Farouk H. Abd El-Aziz, Ali H. Ali and Abdalla I.A. Omar (2015). Effect of Spraying Seaweed Extract and Potassium Silicate on Growth and Fruiting of Al-Saidey Date Palms World Rural Observations 2015; 7(4).

Food Agricultural Organization (F.A.O.). 2009. Quarterly Bulletin of Statistics 6 No. 113: 32 Year book Annual 10 Production 46: 155- 157.

Gad El-Kareem, M.R. (2012). Improving productively of Taimour mango trees by using glutathione, silicon and vitamin B. Minia J. of Agric. Res. \& Develop 32(7): 1105-1121.

Gad El- Kareem, M.R.; Abdel-Aal, A.M.K. and Mohamed A.Y. (2014). The synergistic effect of using silicon and selenium on fruiting of Zaghloul date palm 
(Phoenix dectylifera L.). World Acad. of Sci. Eng. and Tech., Inter. J. of Agric. Biosystems Sci. and Engineering 8(3): 959-964.

Gamal, A. F. (2006). Response of Washington Navel orange trees to some antioxidants and bio fertilization treatments. M.Sc.Thesis Fac. of Agric. Minia Univ. Egypt.

Gamal, A.F.O. (2013). Fruiting of Washington Navel orange trees in relation to application of seaweed extract, boron and citric acid. Ph. D. Thesis Fac. of Agric. Minia Univ. Egypt.

Hasnaoui, A.; M. A Elhoumaizi; A. Hakkou; B. Wathelet, and M. Sindic, (2011). Physico-chemical Characterization, Classification and Quality Evaluation of Date Palm Fruits of some Moroccan Cultivars J. Sci. Res. 3(1),139-149.

Hassaballa, I. A., M. M. Ibrahim, M. M. Sharaf and A. Z. Abd-El- Aziz (1983). Fruit physical and chemical characteristics of Zaghloul date cultivar in response to some fruit thinning treatments Annalles of Agric. Sci. Moshtohor 20: 3-14.

Hussien, F.; M.H. El-Kholy and T.A. Abo Said Ahmed (1993). Organicchemical constituents of some Egyptian dry date cultivars grown at Aswan Zagazig J. Agric Res.20(4) :1313-1321

James, B. (1994). Chapters from life. Ann. Rev. Physio. Plant. Mol. Biolog.45: 1-23.

Khan, W.; Ragirath, M.P; Subramanian, S.; Jithesh, M.N.; Rayorath, P.; Mark Hodges, D.; CritchleyJames,A.T. ; Craigie, J.S.; Nome, C.J. and Prithiviraj, B. (2009). Seaweed extracts as biosimulants of plant growth and development. J. of Plant Growth Regul. (28): 386-399.

Ma, J.F. (2004). Role of silicon in enhancing the resistance of plants of biotic and abiotic stresses. Soil Sci. Plant Nutr. 50:11-18.

Mahmoud, Kh. M.H. (2012). Reducing inorganic $\mathrm{N}$ fertilizer in Balady mandarin orchard through application of extracts of yeast, seaweed and farmyard manure. M. Sc. Thesis Fac. of Agric. Univ. Egypt.

Malaka A. Saleh, Omaima, M. Hafez, N. E. Ashour and E. A. M. Mostafa (2016). Effect of Foliar Spraying with Algae Extract and Potassium Nitrate on Yield and Fruit Quality of cv. Medjool Date Palm Der Pharmacia Lettre, 2016, 8 (8):7278.

Mohamed, A. Y. and El- Sehrawy, O. A. M. (2013): Effect of seaweed extract on fruiting of Hindy Bisinnara mango trees. J. of Amer. Sci. 9 (6): $537-544$.

Mouftah. R.T. (2007). Physiological studies on biofertilization of mango trees cvs Taimour and Zebda. Ph. D. Thesis Fac. of Agric. Minia Univ. Egypt.

Snedecor, C.W. and W.G. Cochran (1990). Statistical methods 7th ed. The Iowa State Univ. Press. Ames Iowa. USA. P. 593.

SeIim; H.H.A., M.A.M. El-Mahdi and M.S. EI-Hakeem, (1968). Studies on the evaluation of fifteen local date cultivars grown under desert condition in Siwa Oasis, U.A.r. bull. De desert d'Egypt, t. XVIII (1): $137+155$.

Snedecor, C.W. and W.G. Cochran (1990). Statistical methods 7th ed. The Iowa State Univ. Press. Ames Iowa. USA. P. 593.

Soliman A.R.L; Hussein, M.H.; Desouki, S.S.A. and Torky, Y. (2000). Production of phyto hormones by some blue green algae used as soil inoculant for rice fields in Egypt. J. Union Arab Biol, Cairo, Vol. (88): Physiology and Algae. 83- 109. 23. 
تاثير الرش بمستخلصات الاعثاب البحرية و السيليكون علي محصول وخصائص ثمار نخيل البلح الزغلول المزروع تحت ظروف الاراضية واضى الرملية

محمد احمد بلدران

معهد بحوث البساتين - مركز البحوث الزر اعية

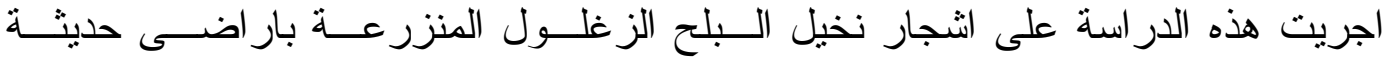

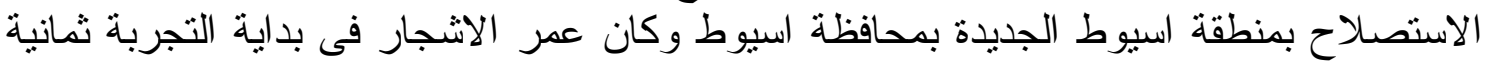

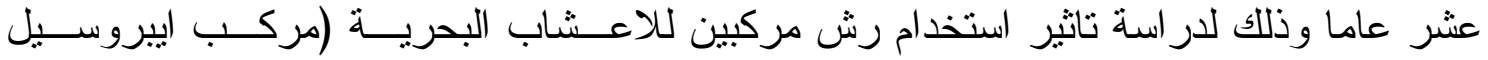

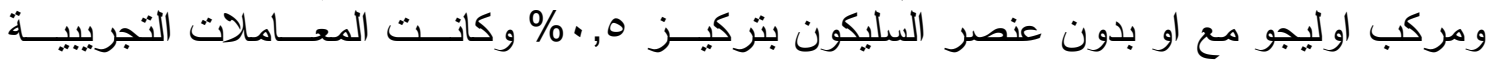

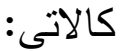
1- آن كونترول (رش الماء فقط)

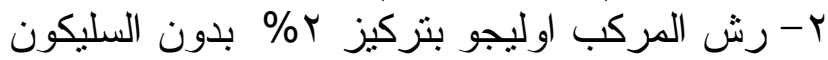

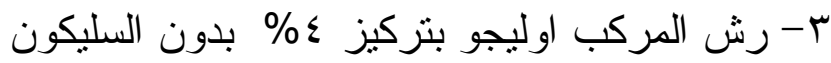

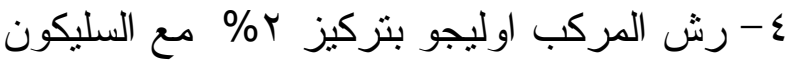

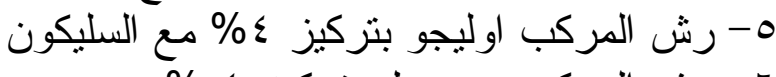

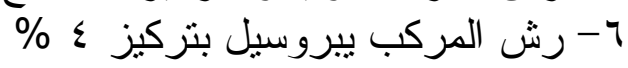

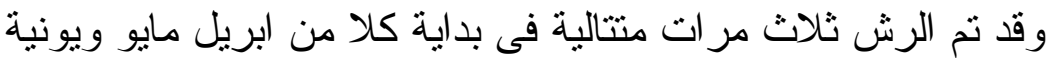

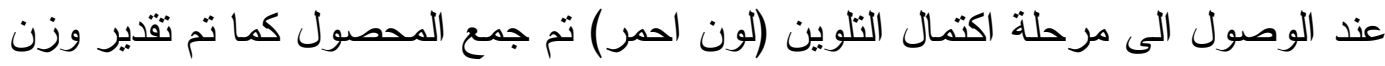

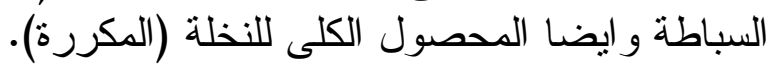

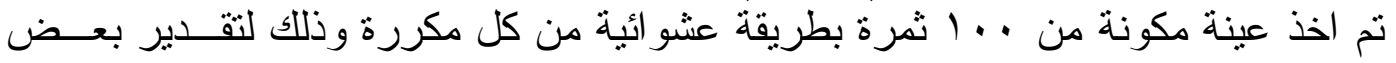
الصفات الطبيعية و الكبميائية. او لا الصفات الطبيعية: الطية وزن وحجم الثمرة ووزن اللحم و ابعاد الثمرة (الطول و القطر) وكذللك وزن البذرة كما تـــ لطم

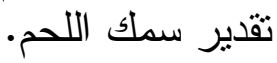
ثانيا الصفات الكيميائية: نسبة المو اد الصلبة الذائبة الكلية و المحتوى من السكريات المختزلة و الكلية و الغير مختزلة

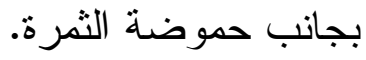
وكان تصميم التجربة قطاعات كاملة العشو ائية وتم مقارنة متوسط المعساملات باسـتخدام

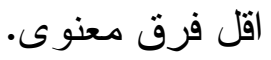

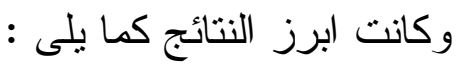

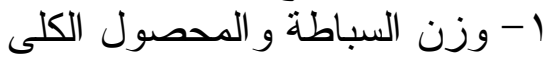

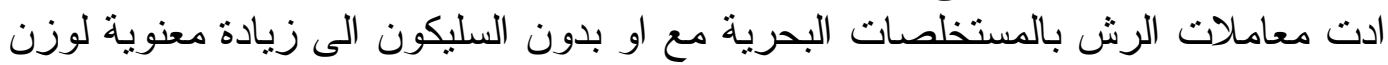

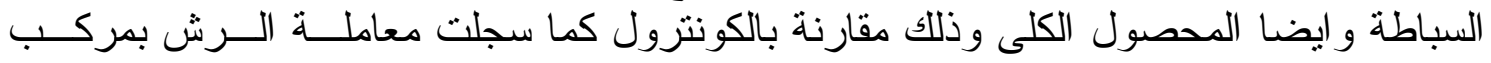

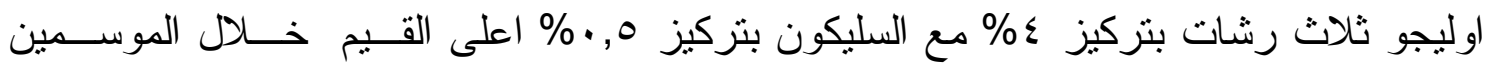

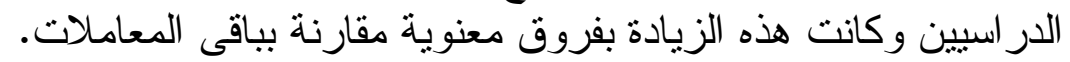

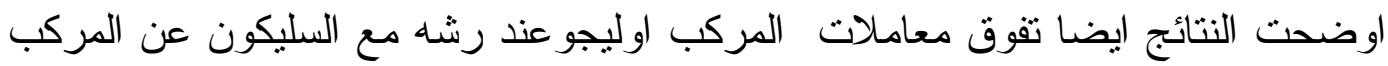

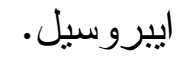

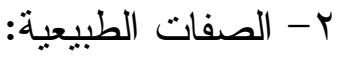

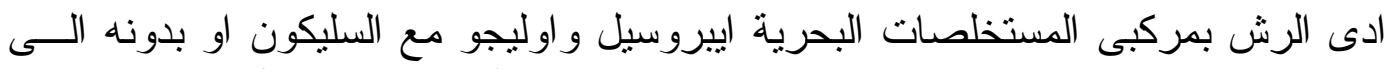

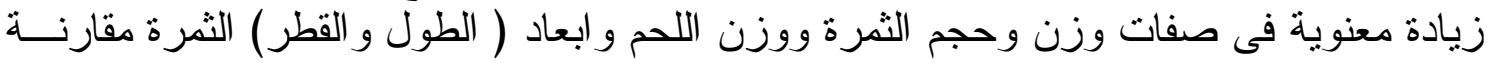

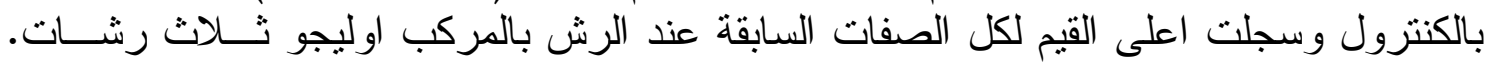




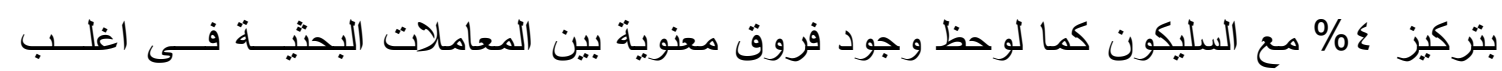

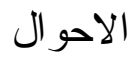

كما لوحظ ايضا ان معاملات الرش بالمستخلصات البحرية مع السليكون او بدونه لم يكن

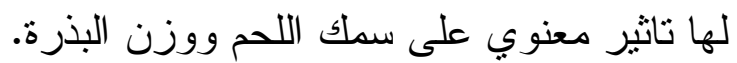
r- الصفات الكيميائية

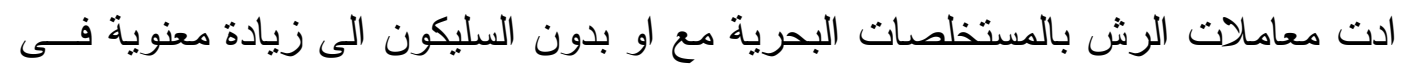

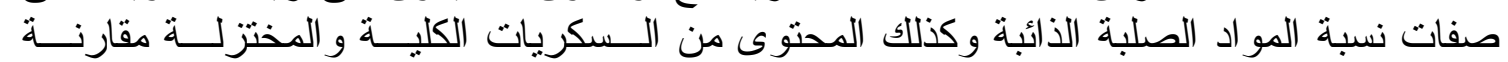

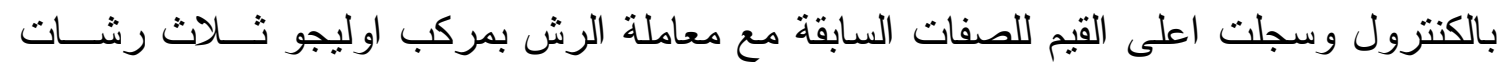

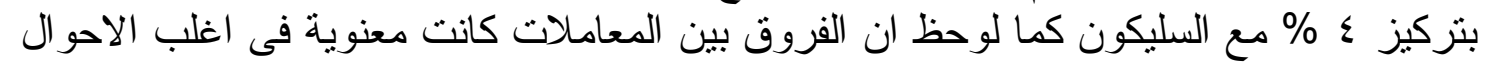

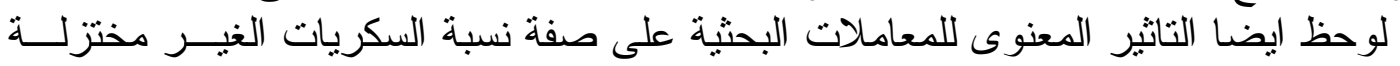

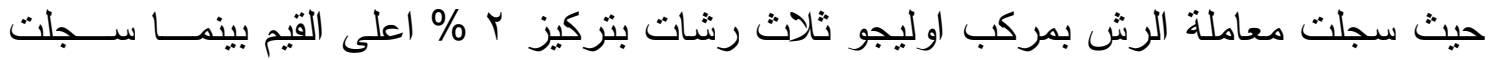

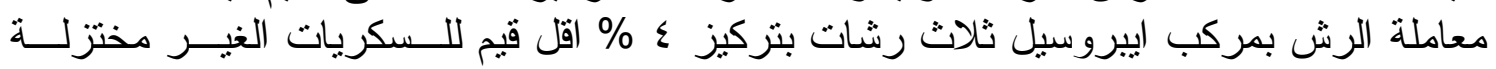
وذلك خلال الموسميين الدر اسيين اليرين اخير ا اوصت الدر اسة تحت ظروف التجربة و الظروف المماتلة يمكن التوصية باســتخدام

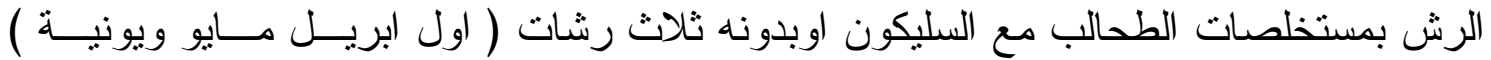

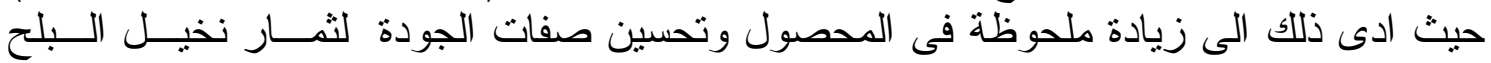

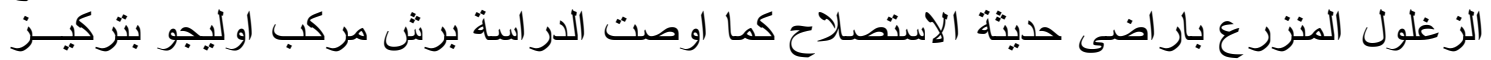

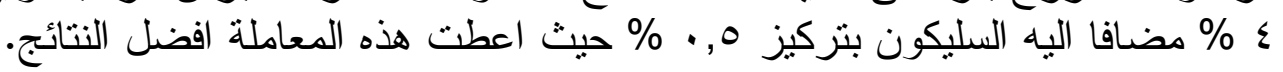

